\title{
Dinamika fatwa produk keuangan syariah
}

\author{
Jaih Mubarok dan Hasanudin \\ Badan Pelaksana Harian Dewan Syari'ah Nasional - Majelis Ulama Indonesia \\ E-mail:jaihmubarok@yahoo.com
}

Fatwa (opinion of jurist/mufti) is developed by mufti/ulama as an instrument of Islamic law as well as guidance for ummah. Fatwa is considered as an actual instrument of Islamic jurisprudence because of certain reasons: a) qaul ulama (jurist's opinion) as another source of Islamic law beside Quran and hadits; b) there is one single authority of fatwa institution in Indonesia; and c) it is a Mufti's response towards real social problems in the society. In fact, some fatwas of National Sharia Board are in harmonize with National Acts (i.e. Act of Central Bank).

Fatwa cenderung dinamis karena sifatnya yang responsif atas persoalan keislaman yang nyata (waqi íyyab) dan penyusunannya juga bersifat dinamis karena menjadikan qaul fuqaha sebagai sumber fatwa di samping sumber utama hukum Islam, yaitu Quran dan Sunah. Karena otoritas fatwa di Indonesia tidak tunggal, maka dinamika fatwa secara horizontal terjadi antara DSN-MUI dan Dewan Hisbah Persis terkait pembiayaan pengurusan haji. Secara vertikal, fatwa berhubungan secara dinamis dengan peraturan perundang-undangan yang berlaku di antaranya fatwa DSN-MUI dan Peraturan Bank Indonesia terkait pembiayaan shirkah.

Keywords: Dynamic; Fatwa; Product; Sharia

\section{Pendahuluan}

Majelis Ulama Indonesia (MUI) memiliki peran yang sangat penting dan strategis (Soekanto,1987: 221; Panggabean, 2008: 31-32) dalam menumbuhkembangkan nilai-nilai muamalah sebagai panduan bisnis. Peran penting dan strategis MUI dimaksud adalah fakta yang menunjukkan bahwa MUI menjadi pelopor dalam sosialisasi, internalisasi, dan memicu pertumbuhan lembaga bisnis syariah, baik lembaga keuangan syariah (bank dan nonbank) maupun lembaga yang tidak terkait dengan bisnis secara langsung. KH Ma'ruf Amin menjelaskan bahwa fatwa merupakan penjelasan hukum syariah kepada pihak yang 
ljtihad, Jurnal Wacana Hukum Islam dan Kemanusiaan, Volume 13, No. 1, Juni 2013: 1-14

menanyakannya (tabyin al-ḥukm shar'iy li-man sa'ala 'anhu) sedangkan al-Barazi menjelaskan bahwa fatwa adalah tabyin al-hukem al-shariy 'an dalil li-man sa'ala 'anbu (Amin, 2012: 7; alBarazi, t.th: 5-6; dan Haroen, 2003: 326-328).

Fatwa dari segi generiknya bersifat dinamis karena respons terhadap persoalan keislaman yang nyara (waqiíyah) di masyaraakat (Mudzhar, 1992: 2-4; Rachman, 1994: 369-370). Oleh karena itu, kiranya layak dipertanyakan hal-hal berikut: 1) bagaimana dinamika penyusunan fatwa; 2) bagaimana dinamika fatwa secara horizontal; dan 3) bagaimana dinamika fatwa secara vertikal.

\section{Dinamika penyusunan fatwa}

Fatwa pada prinsipnya merupakan respon terhadap persoalan hukum Islam yang memerlukan penjelasan. DSN-MUI telah menetapkan standar operasional dan prosedur dalam penyusunan fatwa: pertama, masalah yang diajukan oleh industri/ regulator/ masyarakat ke BPH DSNMUI dilakukan kajian oleh Kelompok Kerja/ Pokja yang relevan dengan melakukan langkahlangkah: 1) case hearing dengan pemohon, 2) klarfikasi dengan pihak terkait, 3) draft formulasi masalah, 4) konfirmasi para pihak, dan 5) formulasi masalah.

Kedua, formulasi masalah disampaikan oleh Pokja kepada BPH DSN-MUI yang selanjutnya dilakukan: 1) kajian hukum yang berupa: a) analisis dalil/ adillah, dan b) analisis terhadap aqwal ulama, 2) industry and regulatory hearing, 3) draft formulasi solusi, 4) konfirmasi kepada regulator, 5) formulasi solusi/draft fatwa.

Ketiga, draft fatwa dari BPH DSN-MUI disampaikan kepada Pleno DSN-MUI untuk diadakan sidang pleno dengan rangkaian kegiatan: 1) presentasi draft fatwa oleh BPH DSNMUI, 2) tanggapan pleno (umum dan khusus), 3) penyempurnaan draft fatwa, 4) harmonisasi dengan fatwa dan regulasi lain, dan 5) persetujuan fatwa (Sam dkk., 2011: 19-20).

Mustafti dalam fatwa DSN-MUI pada umumnya berasal dari: 1) pihak industri, 2) pihak asosiasi, dan 3) pihak regulasi. Pada umumnya fatwa dimintakan kepada DSN-MUI dalam rangka mengembangkan produk atau daya saing produk. Khusus mengenai fatwa nomor: 81/DSN-MUI/III/2011 tentang Pengembalian Dana Tabarru' bagi Peserta Asuransi yang Berbenti sebelum Masa Perjanjian Berakbir, mengalami dinamika segi tiga secara harmonis antara DSN-MUI, regulator (Biro Perasuransian di Kemenkeu RI [sekarang OJK]), dan 
pihak asosiasi (dan industri). Sekarang, tiga pihak ini sudah mencapai "kesepahaman" atas fatwa mengenai pengembalian dana tabarru' tersebut.

Pada umumnya pihak regulator (Bank Indonesia/Kemenkeu) mengajukan fatwa dan atau pernyataan kesesuaian syariah dalam rangka mengembangkan produk dan instrumen investasi (seperti penerbitan sukuk dan efek yang layak dimasukkan ke dalam Daftar Efek Syariah di Bapepam LK). Oleh karena itu, fatwa DSN-MUI dirumuskan dan dibuat dalam rangka menumbuhkembangkan ekonomi syariah di Indonesia, termasuk produk dan instrumen investasinya.

Dari sisi pengembangan produk, sekarang ini pihak perbankan masih menggunakan nama akad sebagai nomenklatur produk perbankan; misalnya: pada sisi funding masih terdapat produk yang berupa: 1) tabungan mudharabah, 2) deposito mudharabah, 3) giro mudharabah, 4) tabungan wadi ${ }^{\circ} a h$, dan 5) giro wadi'ah. Pada sisi financing masih terdapat produk: 1) pembiayaan murabahah, 2) pembiayaan mushärakah, 3) pembiayaan mudharabah, 4) pembiayaan Qard, dan 5) pembiayaan Ijärah.

Menurut ajaran ilmu hukum, akad bernama (al-'uqūd al-musammah) bersifat terbatas; sedangkan akad yang tidak bernama (al-'uqüd ghair musammah) bersifat tidak terbatas. Oleh karena itu, sepanjang pihak industri dan regulasi menggunakan akad-akad bernama dalam produknya, maka produk tersebut bersifat terbatas, sehingga agak sulit berkembang; salah satu cara pengembangan produk menggunakan nama-nama yang bukan akad bernama (Badrulzaman dkk, 2001: 67).

Pengembangan produk dalam artian pengembangan instrument investasi, sekarang ini Direktorat Jenderal Pengelolaan Utang Negara (DJPU) yang dimotori oleh Dahlan Siamat telah memperlihatkan kemajuan yang signifikan; sekarang ini, di samping disediakan instrument investasi jangka menengah (pada umumnya berjangka waktu tiga tahun) disediakan pula instrumen investasi jangka pendek (berjangka waktu kurang dari satu tahun), yaitu Surat Perbendaharaan Negara Syariah (SPN-Syariah).

\section{Dinamika fatwa secara horizontal: kasus pembiayaan pengurusan haji}

Fatwa pada prinsipnya termasuk domain norma hukum; sedangkan penerapan fatwa di LKS pada prinsipnya merupakan upaya mewujudkan norma-norma syariah dalam kehidupan 
nyata yang termasuk domain penerapan hukum (bukan lagi domain norma hukum). Pada tahapan ini, terdapat dua hal yang penting diperhatikan: 1) kualitas pemahaman Sumber Daya Insani terhadap substansi fatwa; dan 2) hubungan antara norma syariah/muamalah dalam fatwa dengan ilmu kontrak (akad) bisnis. Dinamika yang demikian untuk sementara waktu disebut dinamika vertikal. Sedangkan faktanya, fatwa di samping memiliki dinamika secara vertikal, juga berdinamika secara horizontal (sesama institusi/lembaga fatwa atau pihak-pihak tertentu yang merasa memiliki otoritas untuk berfatwa).

DSN-MUI telah menetapkan fatwa nomor: 29/DSN-MUI/VI/2002 tentang Pembiayaan Pengurusan Haji Lembaga Keuangan Syariah; fatwa ini merupakan jawaban terhadap permohonan industri keuangan (bank) yang ingin meningkatkan kualitas pelayanan yang berupa semakin ragamnya metode pembiayaan terhadap masyarakat.

Dalam fatwa DSN nomor: 29/DSN-MUI/VI/2002 tentang Pembiayaan Pengurusan Haji Lembaga Keuangan Syariah, ditetapkan bahwa: 1) dalam pengurusan haji bagi nasabah, LKS dapat memperoleh imbalan jasa (ujrah) dengan menggunakan prinsip al-Ijarah sesuai Fatwa DSN-MUI nomor 9/DSN-MUI/IV/2000; 2) apabila diperlukan, LKS dapat membantu menalangi pembayaran BPIH nasabah dengan menggunakan prinsip al-Qard sesuai Fatwa DSN-MUI nomor 19/DSN-MUI/IV/2001;3) jasa pengurusan haji yang dilakukan LKS tidak boleh dipersyaratkan dengan pemberian talangan haji; dan 4) besar imbalan jasa al-Ijarah tidak boleh didasarkan pada jumlah talangan al-qard yang diberikan LKS kepada nasabah.

Dalam fatwa tersebut berlaku dua akad secara pararel: akad Ijärah sebagai akad utama, dan akad qard sebagai akad pendukung. LKS yang mengurus dan membantu nasabah untuk memperoleh seat/porsi haji dari pihak otoritas berhak mendapatkan ujrah atas pekerjaan yang berupa pelayanan tersebut; oleh karena itu, berlakulah norma Ijarah sebagai terdapat dalam fatwa DSN-MUI, yaitu: pertama, ketentuan Obyek Ijärah adalah: 1) obyek Ijärah adalah manfaat dari penggunaan barang dan/atau jasa; 2) manfaat barang atau jasa harus bisa dinilai dan dapat dilaksanakan dalam kontrak; 3) manfaat barang atau jasa harus yang bersifat dibolehkan (tidak diharamkan); 4) kesanggupan memenuhi manfaat harus nyata dan sesuai dengan syari'ah; 5) manfaat harus dikenali secara spesifik sedemikian rupa untuk menghilangkan jabalah (ketidaktahuan) yang akan mengakibatkan sengketa; 6) spesifikasi 
manfaat harus dinyatakan dengan jelas, termasuk jangka waktunya. Bisa juga dikenali dengan spesifikasi atau identifikasi fisik; 7) sewa atau upah adalah sesuatu yang dijanjikan dan dibayar nasabah kepada LKS sebagai pembayaran manfaat. Sesuatu yang dapat dijadikan harga dalam jual beli dapat pula dijadikan sewa atau upah dalam Ijarah; 8) pembayaran sewa atau upah boleh berbentuk jasa (manfaat lain) dari jenis yang sama dengan obyek kontrak; dan 9) kelenturan (flexibility) dalam menentukan sewa atau upah dapat diwujudkan dalam ukuran waktu, tempat dan jarak; kedua, Kewajiban LKS sebagai pemberi manfaat barang atau jasa: 1) menyediakan barang yang disewakan atau jasa yang diberikan; 2) menanggung biaya pemeliharaan barang; dan 3) menjamin bila terdapat cacat pada barang yang disewakan. Ketiga, kewajiban nasabah sebagai penerima manfaat barang atau jasa adalah: 1) membayar sewa atau upah dan bertanggung jawab untuk menjaga keutuhan barang serta menggunakannya sesuai kontrak; 2) menanggung biaya pemeliharaan barang yang sifatnya ringan (tidak materil); dan 3) jika barang yang disewa rusak, bukan karena pelanggaran dari penggunaan yang dibolehkan, juga bukan karena kelalaian pihak penerima manfaat dalam menjaganya, ia tidak bertanggung jawab atas kerusakan tersebut.

Akad qard antara LKS dengan nasabah berupa pembiayaan dilakukan untuk mendukung pelayanan yang diberikan oleh LKS kepada nasabah dalam rangka membantu nasabah mendapatkan porsi haji sebagaimana dimaksudkan di atas. Untuk hal ini berlakulah ketentuan mengenai pembiayaan qard; yaitu: 1) nasabah qard wajib mengembalikan jumlah pokok yang diterima pada waktu yang telah disepakati bersama; 2) biaya administrasi dibebankan kepada nasabah; 3) LKS dapat meminta jaminan kepada nasabah bilamana dipandang perlu; 4) nasabah qard dapat memberikan tambahan (sumbangan) dengan sukarela kepada LKS selama tidak diperjanjikan dalam akad; dan 5) jika nasabah tidak dapat mengembalikan sebagian atau seluruh kewajibannya pada saat yang telah disepakati dan LKS telah memastikan ketidakmampuannya, LKS dapat memperpanjang jangka waktu pengembalian, atau menghapus (write off) sebagian atau seluruh kewajibannya.

Di antara kekurangan fatwa DSN nomor: 29/DSN-MUI/VI/2002 tentang Pembiayaan Pengurusan Haji Lembaga Keuangan Syariah, adalah tidak terdapat ketentuan mengenai metode/cara mendapatkan ujrah atas jasa pelayanan yang dilakukan oleh LKS; ketentuan yang ada hanya menyatakan bahwa penerimaan ujrah oleh LKS tidak boleh berhubungan 
ljtihad, Jurnal Wacana Hukum Islam dan Kemanusiaan, Volume 13, No. 1, Juni 2013: 1-14

langsung dengan pembiayaan al-qard kepada nasabah. Oleh karena itu, industri menentukan caranya sendiri yang pada akhirnya timbul dugaaan mengenai adanya hubungan langsung antara jumlah ujrah yang diterima LKS dengan pembiayaan qard; sehingga ujrah tersebut dipandang sebagai riba. Padahal sebenarnya tidak demikian.

Dewan Hisbah Pengurus Pusat Persatuan Islam (PP Persis) merespon praktek industri keuangan syariah yang cenderung menyimpang tersebut dengan fatwa tentang "Dana Talangan Haji” yang ditandatangani KH. Usman Shalahuddin (Ketua) dan KH. Zae Nandang (Sekretaris) pada tanggal 11 April 2011/7 Jumadil Ula 1432 H. Isi fatwa tersebut adalah: 1) akad dalam dana talangan haji yang mensyaratkan "ujrah" (imbalan dari pinjaman) bagi talangan pinjaman uang sebesar biaya untuk mendapatkan nomor porsi lebih cepat disebut akad Ijarah tidak tepat; 2) beban biaya yang ditanggung oleh peminjam dana talangan haji termasuk syarat mendapat pinjaman dana talangan haji; 3) besaran beban biaya yang ditanggung peminjam dana talangan haji bergantung atas lamanya waktu pelunasan pembayaran disebut ujrah tidak tepat; dan 4) beban pembayaran yang ditanggung peminjam dana talangan haji umpamanya sebesar Rp.1.200.000 untuk satu tahun masa pelunasan pinjaman, dan Rp.2.400.000 untuk dua tahun masa pelunasan pinjaman dan seterusnya, adalah riba.

Dilihat secara substantif, antara fatwa DSN-MUI Nomor: 29/DSN-MUI/VI/2002 tentang Pembiayaan Pengurusan Haji Lembaga Keuangan Syariah, dengan fatwa Dewan Hisbah PP Persis tentang "Dana Talangan Haji” tidaklah terdapat pertentangan; hanya saja komunikasi efektif antara DSN-MUI dengan Dewan Hisbah PP Persis tidak terbangun sehingga terjadi kekuranglengkapan informasi; sebab: 1) akad pembiayaan dari LKS ke nasabah guna menalangi dana haji dalam fatwa DSN-MUI Nomor 29 Tahun 2002, bukanlah akad Ijarah, tapi akad qard; 2) beban biaya/imbalan (kecuali biaya administrasi) yang ditanggung oleh nasabah bukan merupakan syarat pembiayaan qard; sebab imbalan yang dijadikan syarat dalam pembiayaan qard adalah haram (riba) juga hukumnya berdasarkan fatwa DSN-MUI; dan 3) akad Ijärah yang dimaksud dalam fatwa DSN nomor 29 Tahun 2002 adalah Ijärah atas jasa LKS yang berupa layanan pengurusan porsi haji. 


\section{Dinamika fatwa secara vertikal: hubungan fatwa dan regulasi}

Fatwa DSN-MUI tentang musharakah tersebar dalam empat fatwa: 1) fatwa nomor 08/ DSN-MUI/IV/2000 tentang Pembiayaan Musyarakah; 2) fatwa nomor 50/DSN-MUI/ III/2006 tentang Mudharabah Musytarakah; 3) fatwa nomor 51/DSN-MUI/III/2006 tentang Mudharabah- Musytarakah pada asuransi syariah; dan 4) Fatwa Nomor 73/DSNMUI/XI/2008 tentang Syrikah-Mutanäqisah. Antara fatwa yang satu dengan fatwa yang lain bersifat saling melengkapi. Akan tetapi, dalam konteks ini yang dibahas hanya dua topik, yaitu mushärakah dan mushärakah mutanāqisah (MMQ).

Dalam fatwa DSN-MUI Nomor 08 Tahun 2000 tentang Pembiayaan Musyarakah Ketentuan mengenai pihak-pihak yang melakukan kontrak musyarakah adalah bahwa mereka harus cakap hukum dengan memperhatikan: 1) kompetensi dalam memberi atau menerima kuasa; 2) setiap syarik menyediakan dana dan pekerjaan; setiap syarik melaksanakan kerja sebagai wakil dari syarik yang lainnya; 3) setiap syarik memiliki hak untuk mengatur aset mushärakah dalam proses bisnis normal; 4) setiap syarik memberi wewenang kepada syarik yang lain untuk mengelola aset dan masing-masing dianggap telah diberi wewenang untuk melakukan aktivitas mushärakah dengan memperhatikan kepentingan syarik lainnya, tanpa melakukan kelalaian dan kesalahan yang disengaja; dan 5) syarik tidak diizinkan untuk mencairkan atau menginvestasikan dana untuk kepentingannya sendiri (Ibn Ahmad, 1979: 130).

Ketentuan mengenai obyek kontrak mushärakah berhubungan dengan ketentuan mengenai modal, kerja, keuntungan, dan kerugian. Pertama, ketentuan mengenai modal adalah: 1) modal yang diberikan dalam bentuk uang tunai, emas, perak, atau yang nilainya sama. Modal dapat berupa aset perdagangan, seperti barang-barang, properti, dan sebagaimanya. Jika modal berbentuk aset, terlebih dahulu dinilai dengan tunai dan disepakati oleh para syarik (Shawi, 1990: 164-165; dan Tanukhi, t.th: 36);2) para pihak tidak boleh meminjam, meminjamkan, mengahadiahkan modal musharakah kepada pihak lain, kecuali atas dasar kesepakatan; dan 3) dalam pembiayaan musharakah tidak ada jaminan, namun untuk menghindari terjadinya penyimpangan, Lembaga Keuangan Syari'ah/LKS (Lembaga Bisnis Syari'ah/LBS) dapat meminta jaminan.

Kedua, ketentuan mengenai kerja adalah: 1) partisipasi para syarik dalam pekerjaan merupakan dasar pelaksanaan mushärakah. Akan tetapi, salah satu syarik boleh melaksanakan 
ljtihad, Jurnal Wacana Hukum Islam dan Kemanusiaan, Volume 13, No. 1, Juni 2013: 1-14

kerja lebih banyak dari yang lainnya; dan ia boleh menuntut bagian keuntungan tambahan bagi dirinya; dan 2) setiap syarik melaksanakan kerja dalam musharakah atas nama shirkah. Kedudukan masing-masing dalam organisasi kerja dijelaskan dalam kontrak.

Ketiga, ketentuan mengenai keuntungan adalah: 1) kentungan dihitung dengan jelas untuk menghindari perbedaan dan sengketa pada waktu alokasi keuntungan atau ketika penghentian mushärakab; 2) setiap keuntungan mushärakah dibagikan secara proporsional atau atas dasar kesepakatan yang ditentukan di awal akad; 3) syarik boleh mengusulkan bahwa jika keuntungan melebihi jumlah tertentu, kelebihan atau prosentase itu diberikan kepadanya; dan 4) sistem pembagian keuntungan (nisbah) tertuang dengan jelas dalam akta perjanjian (Mishri, 2007: 226).

Keempat, ketentuan mengenai kerugian adalah bahwa kerugian dibagi di antara para syarik secara proporsional menurut saham (porsi) masing-masing dalam modal. Kelima, ketentuan mengenai biaya operasional dan persengekatan dalam akad mushärakah adalah: 1) biaya operasional dibebankan pada modal bersama; dan 2) jika salah satu pihak tidak menunaikan kewajibannya atau jika terjadi perselisihan di antara para pihak, penyelesaiannya dilakukan melalui Badan Arbitrase Syariah (Basyarnas) setelah tidak tercapai kesepakatan melalui musyawarah.

Dalam fatwa tersebut terdapat dua ketentuan yang menarik: pertama, keuntungan mushärakah dibagi berdasarkan porsi modal atau sesuai kesepakatan yang dituangkan secara jelas dalam klausula akta perjanjian. Oleh karena itu, pembagian keuntungan dapat dilakukan dengan salah satu dari dua cara; dibagi secara proporsional (sesuai dengan proporsi/ prosentase modal) atau dibagi sesuai kesepakatan (tidak berdasarkan proporsi modal); dan kedua, kerugian dibagi di antara para syarik secara proporsional menurut saham (porsi) masing-masing dalam modal. Oleh karena itu, apabila dalam perjanjian mushärakab terdapat klausula yang menyatakan bahwa kerugian ditanggung sesuai kesepakatan (tidak proporsional), maka klausula tersebut batal demi hukum.

DSN-MUI juga telah mengeluarkan fatwa nomor 73/DSN-MUI/XI/2008 tentang Syrikah-Mutanāqisah yang substansinya terdiri atas lima bagian: 1) ketentuan umum, 2) ketentuan hukum, 3) ketentuan akad, 4) ketentuan khusus, dan 5) penutup. 
Ketentuan umum fatwa tentang Shirkah-Mutanäqișah terdiri atas empat bagian: 1) mushärakah-mutanāqisah atau shirkah yang kepemilikan asset/barang atau modal salah satu syarik berkurang disebabkan pembelian secara bertahap oleh syarik lainnya; 2) syarik adalah mitra; yaitu pihak yang melakukan akad musharakab; 3) bisssah adalah porsi modal atau bagian syarik dalam kekayaan mushärakah yang bersifat musa'; dan 4) musa' adalah porsi atau bagian syarik dalam kekayaan mushärakah (milik bersama) dari segi nilai dan tidak dapat ditentukan batas-batasnya secara fisik.

Ketentuan hukum mushärakah-mutanaqisah adalah boleh; dan ketentuan akadnya terdiri atas lima bagian: 1) akad mushärakah-mutanäqisah terdiri atas akad shirkah dan akad jual-beli (yang dilakukan secara pararel); 2) ketentuan bagi syarik dalam mushärakah-mutanäqisah adalah: a) berkewajiban menyertakan harta untuk dijadikan modal usaha dan kerja berdasarkan kesepakatan dalam akta, b) berhak memperoleh keuntungan berdasarkan nisbah yang disepakati pada saat akad, dan c) menanggung kerugian sesuai porsi modal; 3) dalam akad mushärakah-mutanāqisah, syarik wajib berjanji untuk menjual seluruh hisssah-nya secara bertahap, dan syarik lain wajib membelinya; 4) jual-beli dilakukan sesuai kesepakatan; dan 5) setelah selesai seluruh proses jual-beli, seluruh ḥissah Lembaga Keuangan Syari'ah/LKS beralih kepada syarik lainnya/nasabah.

Ketentuan khusus fatwa tentang mushärakah-mutanāisah terdiri atas lima bagian: 1) aset mushärakah-mutanāqisah dapat di-ijärah-kan (disewakan) kepada syarik atau pihak lain; 2) apabila asset mushärakah-mutanäqisah menjadi obyek ijärah, maka syarik/nasabah dapat menyewa asset tersebut dengan nilai ujrah (sewa) berdasarkan kesepakatan; 3) keuntungan yang diperoleh dari usaha tersebut (hasil sewa) dibagi sesuai dengan nisbah yang telah disepakati dalam akad, sedangkan pembagian kerugian harus berdasarkan porsi modal/kepemilikan. Nisbah keuntungan dapat mengikuti proporsi modal/kepemilikan sesuai kesepakatan para syarik; 4) kadar/ukuran bagian/porsi kepemilikan asset mushārakah dari pada syarik/LKS berkurang akibat pembayaran oleh syarik/nasabah harus jelas dan disepakati dalam akad; dan 5) biaya perolehan asset mushärakah-mutanäqisah menjadi beban bersama, sedangkan biaya peralihan kepemilikan menjadi beban pembeli.

Ketentuan penutup fatwa tentang mushärakah-mutanāqisah terdiri atas dua bagian: 1) jika terjadi perselisihan di antara para pihak, penyelesaian perselisihan dilakukan berdasarkan 
Ijtihad, Jurnal Wacana Hukum Islam dan Kemanusiaan, Volume 13, No. 1, Juni 2013: 1-14

peraturan perundang-undangan yang berlaku dan sesuai prinsip syari'ah; dan 2) fatwa tentang mushärakah-mutanāqisah berlaku sejak tanggal ditetapkan (14 November 2008 M) dengan ketentuan jika di kemudian hari ternyata terdapat kekeliruan, akan diubah dan disempurnakan sebagaimana mestinya.

Fatwa DSN-MUI nomor 08/DSN-MUI/IV/2000 tentang Pembiayaan Mushärakah, dan fatwa DSN MUI nomor 73/DSN-MUI/XI/2008 tentang Shirkah-Mutanäqisah, terkait dengan Peraturan Bank Indonesia nomor 7/46/PBI/2005 tentang Akad Penghimpunan dan Penyaluran Dana bagi Bank yang Melaksanakan Kegiatan Usaha Berdasarkan Prinsip Syariah, yang kemudian dilengkapi dengan Peraturan Bank Indonesia Nomor 9/19/PBI/ 2007 tentang Pelaksanaan Prinsip Syariah dalam Kegiatan Penghimpunan dan Penyaluran Dana serta Pelayanan Jasa Bank Syariah.

Dalam kitab fikih dijelaskan bahwa nisbah bagi hasil dapat dilakukan dengan dua cara: proporsional dan kesepakatan. Bagi hasil secara proporsional yang dimaksud adalah bahwa keuntungan usaha dibagi sesuai dengan proporsi (prosentase) modal yang disbirkabkan; sedangkan yang dimaksud dengan bagi hasil dengan cara kesepakatan adalah bahwa tidak mesti berbanding lurusnya (linier) antara proporsi modal yang dishirkabkan dengan prosentase kuntungan yang diterima oleh Syarik. Dalam Peraturan Bank Indonesia Nomor 7/46/ PBI/2005 ditetapkan bahwa pembagian keuntungan berdasarkan nisbah yang disepakati sebelumnya. Misal Ahmad dan Hamid masing-masing menyertakan modal mushärakah 100 juta rupiah (proporsi modal $50: 50$ ); tetapi nisbah keuntungan yang disepakati adalah 70: 30. Maka Nisbah 70: 30 ditetapkan atas dasar kesepakatan; sedangkan apabila nisbahnya ditetapkan secara proporsional, maka Nisbah pembagian keuntungannya adalah $50: 50$. Dengan demikian, secara implisit peraturan tersebut menafikan pembagian keuntungan secara proporsional dalam akad mushärakah. Hal ini dikuatkan dengan ketentuan yang terdapat pada pasal lainya yang menyatakan bahwa pembagian keuntungan dari pengelolaan dana dinyatakan dalam bentuk nisbah yang disepakati.

Meskipun tidak diatur dalam syarat-syarat pembiayaan musharakah secara langsung. Peraturan Bank Indonesia, pengembalian dana milik Bank untuk usaha shirkah yang bersifat modal kerja (dan pemblian hishah milik Bank untuk usaha shirkah yang bersifat modal investasi/inventori), ditentukan dalam pasal mengenai syarat-syarat pembiayaan mudharabah. 
Di antara syarat pembiayaan mudharabah adalah bahwa dalam hal nasabah ikut menyertakan modal dalam kegiatan usaha yang dibiayai Bank, maka berlaku ketentuan: 1) nasabah bertindak sebagai mitra usaha dan mudārib,2) atas keuntungan yang dihasilkan dari kegiatan usaha yang dibiayai tersebut, maka nasabah mengambil bagian keuntungan dari porsi modalnya, sisa keuntungan dibagi sesuai kesepakatan antara Bank dan nasabah, dan 3) pengembalian pembiayaan dilakukan pada akhir periode akad untuk pembiayaan dengan jangka waktu sampai dengan satu tahun atau dilakukan secara angsuran berdasarkan aliran kas masuk (cash in flow) usaha nasabah. Ketentuan ini pada dasarnya merupakan pengaturan mushärakah (bukan mudharabah); oleh karena itu, dalam praktek perbankan ditentukan bahwa modal bank wajib dikembalikan secara sekaligus di akhir periode/jangka waktu usaha mushärakah yang jangka waktunya kurang dari satu tahun; sedangkan modal bank wajib dikembalikan secara berangsur (bertahap) bagi usaha mushärakah yang jangka waktunya lebih dari satu tahun.

Ketentuan mengenai metode pengembalian modal milik Bank dalam usaha yang berbasis akad shirkab menunjukkan bahwa pembiayaan sbirkah diregulasi oleh Bank Indonesia sebagai pembiayaan jangka pendek dan jangka panjang. Dalam fatwa DSN-MUI, terutama fatwa nomor 08/DSN-MUI/IV/2000 tentang Pembiayaan Musyarakah, dan fatwa Nomor 73/ DSN-MUI/XI/2008 tentang mushärakah mutanäqisah, hanya dibedakan dari segi metode pengembalian modal sbirkah milik bank; yaitu fatwa nomor 08/DSN-MUI/IV/2000 tentang Pembiayaan Musyarakah tidak menentukan mengenai metode pengembalian modal shirkah milik bank; sedangkan fatwa DSN-MUI Nomor 73/DSN-MUI/XI/2008 tentang mushärakah mutanäqisah ditentukan mengenai metode pengembalian modal shirkah milik bank, yaitu pengembalian dilakukan secara berangsur/bertahap sesuai kesepakatan.

Ketentuan Peraturan Bank Indonesia Nomor 7/46/PBI/2005, pasal 7 huruf $m$ dan huruf $\mathrm{n}$, menunjukkan bahwa Bank Indonesia menempatkan pembiayaan mushärakah menjadi dua macam: 1) shirkah yang termasuk pembiayaan jangka pendek; yaitu pembiayaan yang kurang dari satu tahun; dan 2) shirkah yang termasuk pembiayaan jangka panjang; yaitu pembiayaan yang lebih dari satu tahun. Setiap pembiayaan musharakah yang lebih dari satu tahun hanya dibolehkan dengan menggunakan akad mushärakah mutanāisisah; oleh karena itu, meskipun nomenklatur sebuah kontrak tertulis shirkah mushärakah (bukan mushärakah mutanaquisah), tetapi jangka waktunya lebih dari satu tahun, serta pengembalian modal milik 
Ijtihad, Jurnal Wacana Hukum Islam dan Kemanusiaan, Volume 13, No. 1, Juni 2013: 1-14

bank dilakukan secara berangsur, maka akad tersebut secara substantif termasuk akad mushārakah mutanāqisah. Dengan demikian, fatwa DSNMUI nomor 08/DSN-MUI/IV/ 2000 tentang Pembiayaan Musyarakah dipositivasi oleh Bank Indonesia sebagai pembiaayan jangka pendek, sedangkan fatwa DSN-MUI Nomor 73/DSN-MUI/XI/2008 tentang Syirkah-Mutanāissah dipositivasi oleh Bank Indonesia sebagai pembiaayan jangka panjang. Sedangkan fatwanya sendiri (DSNMUI nomor 08/DSN-MUI/IV/2000 tentang Pembiayaan Musyarakah, dan fatwa Nomor 73/DSN-MUI/XI/2008 tentang ShirkahMutanāqisah) tidak dimaksudkan sebagai media untuk membentuk pembiayaan jangka pendek maupun jangka panjang; karena ajaran Islam tentang musharakah/shirkah pada dasarnya ulama tidak menghubungkannya secara langsung dengan sifat waktu dari akad itu sendiri. Ulama menjelaskan bahwa perbedaan esensial antara akad mushärakah dengan mushärakah mutanāissab terletak pada berkurangnya modal salah satu syarik (bank) karena dikembalikan oleh syarik lainnya (Nasabah) secara berangsur sesuai kesepakatan.

Pembatasan bahwa akad mushärakah berlaku untuk pembiayaan jangka pendek dan pembiayaan mushārakah-mutanāișah berlaku untuk pembiayaan jangka panjang tidak dipersoalkan oleh DSN-MUI dan para pebisnis rupanya karena memiliki akar historis yang cukup panjang. Sebelum DSN-MUI dibentuk, di antara pihak yang berperan dalam menentukan fatwa secara nasional di Indonesia adalah Komisi Fatwa Majelis Ulama Indonesia. Di antara ketua Komisi Fatwa MUI yang sangat masyhur di Indonesia adalah KH Ibrahim Hosen. Beliaulah yang mengembangkan cara berijtihadyang berdimensi regional Indonesia yang sangat memperhatikan hubungan antara teks wahyu dengan konteksnya, yaitu kemashlahatan.

\section{Penutup}

Fatwa DSN-MUI dibuat atas permohonan pihak mustafti (industri/asosiasi/regulator) yang pada umumnya bermaskuduntuk dijadikan panduan dalam penyusunan regulasi bisnis dengan sistem syariah, dan/atau dijadikan panduan bisnis bagi pihak industri. Fatwa dalam hubungannya dengan teori pilihan perubahan, fatwa cenderung bersifat dinamis karena posisinya selalu berada pada pilihan di antara situasi yang kontradiktif (ta'árud). 
Terkait pengembangan produk keuangan syariah, pihak regulasi dan industri syariah serta asosiasi sebaiknya tidak menggunakan akad bernama (al-'uqüd al-musammah) sebagai nomenklatur produk; karena penggunaan akad bernama sebagai nomenklatur produk bersifat terbatas; supaya tidak terbatas, gunakanlah nama-nama lain dalam produk sehingga pada saatnya produk keuangan syariah dan instrumen investasinya berkembang sedemikian rupa.

Fatwa bersifat dinamis karena pada prinsipnya merupakan respons mufti (ulama) terhadap pertanyaan mustafti (industri/regulator/asosiasi) dalam rangka menumbuhkembangkan dan mensyariahkan ekonomi syariah di Indonesia. Dari segi penyusunan, fatwa dibahas secara bersama antara pihak industri, regulator, dan asosiasi untuk mencari hubungan yang harmonis antara nilai-nilai syariah dengan regulasi (untuk pengendalian dan kontrol) dan penerapan hukumnya (prakteknya di industri keuangan syariah). Di samping itu, penyusunan fatwa bersifat dinamis karena qaul fuqaha dijadikan sebagai sumber fatwa; karena qaul fuqaha banyak khilafiyahnya.

Otoritas fatwa di Indonesia tidak tunggal, di antaranya telah terjadi hubungan dinamis antara DSN-MUI dan Dewan Hisbah Persis terkait fatwa pembiayaan pengurusan haji. Secara vertikal, fatwa berhubungan secara dinamis dengan peraturan perundang-undangan yang berlaku di antaranya keterkaitan antara fatwa DSN-MUI dan Peraturan Bank Indonesia terkait pembiayaan shirkah.

\section{Daftar pustaka}

Amin, KH Ma'ruf (Tim Penyusun). Himpunan Fatwa Majelis Ulama Indonesia. Jakarta: Erlangga, 2011.

Amin, KH Maruf. 'Pembaharuan Hukum Ekonomi Syariah dalam Pengembangan Produk Keuangan Kontemporer (Transformasi Fikih Muamalat dalam Pengembangan Ekonomi syariah)," dalam Pidato Ilmiah pada Penganugeraban Gelar Doktor Kehormatan (Doctor Honoris Causa) dalam Bidang Hukum Ekonomi Syariah di Kampus UIN Syarif Hidayatullah Jakarta, tanggal 5 Mei 2012.

Anonimous. Petunjuk Pelaksanaan Pembukaan Kantor Bank Syariah. Jakarta: Bank Indonesia, 1999.

Badrulzaman, Mariam Darus, dkk. Kompilasi Hukum Perikatan: Dalam Rangka Memperingati Memasuki Masa Purna Bakti Usia 70 Tahun. Bandung: PT Citra Aditya Bakti, 2001. 
ljtihad, Jurnal Wacana Hukum Islam dan Kemanusiaan, Volume 13, No. 1, Juni 2013: 1-14

Barazi, Muhammad Fu'ad. Mas'uliyat al-Fatwa al-Shariyah wa Dhawabituha wa Atsaruba fi Rasyadal-Ummah. t.t: t.pn. t.th.

Fatwa Dewan Hisbah Pengurus Pusat Persatuan Islam (PP Persis) tentang "Dana Talangan Haji" yang ditandatangani KH Usman Shalahuddin (Ketua) dan KH Zae Nandang (Sekretaris) pada tanggal 11 April 2011/7 Jumadil Ula 1432 H.

Fatwa DSN-MUI nomor 81/DSN-MUI/III/2011 tentang Pengembalian Dana Tabarru' bagi Peserta Asuransi yang Berhenti sebelum Masa Perjanjian Berakhir.

Fatwa DSN-MUI Nomor: 19/DSN-MUI/VI/2002 tentang Pembiayaan al-Qard.

Fatwa DSN-MUI Nomor: 29/DSN-MUI/VI/2002 tentang Pembiayaan Pengurusan Haji Lembaga Keuangan Syariah.

Haroen, Nasrun (ed.). Ensiklopedi Hukum Islam. Jakarta: PT Ichtiar Baru van Hoeve. 2003. Ibn Ahmad, Muhammad. Fath al-Rahìm 'ala Figh al-Imām Mälik bi al-Adillah. Beirut: Dar alFikr, 1979.

Mishri, Rafiq Yunus, al-. Fiqh al-Mu'amalat al-Maliyah. Damaskus: Dar al-Qalam. 2007.

Mudzhar, M. Atho. "Penerapan Pendekatan Sejarah Sosial dalam Hukum Islam”, makalah disampaikan dalam acara diskusi yang diselenggarakan oleh Pusat Pengkajian Unisba, di Bandung pada tanggal 8 Januari 1992.

Panggabean, Henry Pandapotan. Peranan Mabkamah Agung Melalui Putusan-Putusan Hukum Perikatan. Bandung: PT Alumni, 2008.

Peraturan Bank Indonesia Nomor 7/46/PBI/2005.

Rachman, Budhy Munawar (ed.). Kontekstualisasi Doktrin Islam dalam Sejarah. Jakarta: Yayasan Wakaf Paramadina, 1994.

Sam, H.M. Ichwan, dkk (Tim Penyunting). Tanya Jawab Seputar Dewan Syariah Nasional Majelis Ulama Indonesia. Jakarta: DSN-MUI, 2011.

Shawi, MuhammadShalah Muhammad, al-. Mushkilät al-Istismar fi al-Bunuk al-Islämiyah wa Kaifa 'Alajaha al-Islam. Al-Manshurah: Dar al-Wafa, 1990.

Soekanto, Soerjono. Sosiologi: Suatu Pengantar. Jakarta: PT RajaGrafindo Persada, 1987.

Tanukhi, Imam Sahnun Ibn Sa’id, al- Al-Mudawwanah al-Kubra. Beirut: Dar al-Fikr, t.th. 